\title{
Bibliometric Analysis of Green Marketing Research from 1977 to 2020
}

\author{
Farida Saleem $^{1}{ }^{(0}$, Amira Khattak ${ }^{2}\left(\mathbb{0}\right.$, Shafiq Ur Rehman ${ }^{3, *}$ and Murtaza Ashiq ${ }^{4}(\mathbb{D}$ \\ 1 Department of Management, College of Business Administration, Prince Sultan University, \\ Riyadh 11586, Saudi Arabia; fsaleem@psu.edu.sa \\ 2 Department of Marketing, College of Business Administration, Prince Sultan University, \\ Riyadh 11586, Saudi Arabia; akhattak@psu.edu.sa \\ 3 Deanship of Library Affairs, Imam Abdulrahman Bin Faisal University, Dammam 31441, Saudi Arabia \\ 4 Library and Information Science, Islamabad Model College for Boys, H-9, Islamabad 44000, Pakistan; \\ gmurtazaashiq00@gmail.com \\ * Correspondence: suRehman@iau.edu.sa
}

Citation: Saleem, F.; Khattak, A.; Ur Rehman, S.; Ashiq, M. Bibliometric Analysis of Green Marketing Research from 1977 to 2020. Publications 2021, 9, 1. https://doi. org $/ 10.3390 /$ publications 9010001

Received: 8 October 2020 Accepted: 17 December 2020 Published: 8 January 2021

Publisher's Note: MDPI stays neutral with regard to jurisdictional clai$\mathrm{ms}$ in published maps and institutional affiliations.

Copyright: $\odot 2021$ by the authors. Licensee MDPI, Basel, Switzerland. This article is an open access article distributed under the terms and conditions of the Creative Commons Attribution (CC BY) license (https:// creativecommons.org/licenses/by/ $4.0 /)$.

\begin{abstract}
The scientific community's growing interest in green marketing research can be traced through the abundance of published literature on the topic. However, there is still a lack of a comprehensive and systematic research focusing on the evolution of this field. The main objective of this paper was to consolidate the state-of-the-art research on green marketing through a bibliometric study of articles published from 1977 to 2020, and to analyze and present the results from the perspective of growing trends in the field; productive and influential countries, institutions, authors, articles, and research journals; keywords; authorship patterns; and international collaborations. The study results indicate a gradual increase in green marketing research from 1977 to 2020, more so in the last five years. A total of 1025 scholarly documents were published in 634 journals during this period and listed in the Web of Science (WOS). The top 10 most productive countries were then analyzed. A great number of institutions from both developing countries (in terms of article count) and developed countries (in terms of citation scores), were compared. Finally, based on keywords and a threefactor analysis, it was concluded that green marketing, sustainability, sustainable development, environment marketing and sustainable marketing have attracted extensive attention during the past decade as keywords.
\end{abstract}

Keywords: bibliometric green marketing; ecological marketing; sustainable marketing; environmental marketing; citation analysis; green marketing

\section{Introduction}

Green marketing consists of all marketing activities designed and implemented to satisfy human needs in ways that do not have a negative impact on the environment [1]. Marketing is not simply sales and advertisements. It includes a broad range of additional activities such as product ideation, manufacturing, packaging, promotion and distribution. Similarly, green marketing incorporates a broad range of marketing activities that may include product design and redesign, green manufacturing and integrated marketing communication, etc. Green marketing is also termed as ecological marketing [2], sustainable marketing [3], eco marketing [4], enviropreneurial marketing [5,6] and environmental marketing $[7,8]$. Sustainable marketing is a term that commonly represents green marketing, even though sustainability as a concept can be controversial, open to multiple interpretations, and difficult to translate into meaningful actions due to the political, economic and technological constraints faced by companies and governments [9] (p. 752). Sustainability and sustainable marketing include three main elements: environmental, social, and economic [3], whereas green marketing mainly focuses on environmental factors. It starts with the consumers, has a long-term approach and involves complete utilization of a company's resources for innovation [10]. 
While the importance of green marketing has been well documented within the marketing discipline, it has also gained increased interest from consumers and many nongovernmental organizations (NGOs) in recent years. There is growing awareness among consumers regarding environmental preservation as well as ethical and sustainable manufacturing and marketing of goods. [11]. Various governments and regional regulatory bodies have also legislated to decrease the impact of the manufacturing and marketing of products on the environment [12]. The European Union (EU)'s environmental tax is an example of such regulation implemented at the regional level [13].

The importance and evolution of green marketing research invite an analysis of the discipline from the quality and quantity perspectives. There are many ways to assess and evaluate the quantity and quality of research in an any scientific discipline. Bibliometric analysis was chosen for the purpose of this study as it can be used to assess the progress, publishing trends and patterns of a discipline [14]. One of the biggest strengths of bibliometric analysis is its capacity to evaluate the published research without directly contacting the authors [15]. Several areas of marketing research, generally, and green or environmental marketing, specifically (a few), have applied bibliometric analysis to assess the evolution of the field. The areas studied so far have been related to general marketing [15], industrial marketing [16,17], digital marketing [18,19] and more recently, green marketing [8,20,21] Only two studies on green marketing were identified and it was seen that they had used few search terms, like "green marketing", "sustainable marketing" and "environmental marketing", or "sustainab" and "marketing", and analyzed articles/research from 1969 to 2008 and from 2009 to 2018, respectively. The former study focused on the characteristics of authors and the thematic and methodological areas of manuscripts written on the subject, while the latter study covered the active and sub-areas of green marketing research. Furthermore, both bibliometric studies had covered (published) journal papers written in the English language only.

Even though green marketing is a major subfield and an emerging area of marketing, there is limited bibliometric analysis available on the topic. There is a need to identify and track the latest developments in the field. This can be achieved by using multiple relevant and comprehensive keywords and by using the most authentic worldwide indexing and abstracting database, i.e., Web of Science (WOS), and investigating areas left unexplored by previous bibliometric studies (citations, productivity, affiliations of authors, collaborations of authors and countries, etc.). Such a focused approach can be used to extract meaningful and comprehensive findings regarding the green marketing literature. Another way to expand the scope of research on green marketing is to include book chapters and conference proceedings (all academic materials) published in all languages. It is notable that there is limited research available on bibliometric analysis in green marketing, as majority of studies conducted on the topic have only focused on systematic reviews of literature [22,23]. Only one bibliometric study was found, and it had only focused on greenwashing, a subarea of green marketing [24]. Other studies conducted to date, have focused on reviews, content analysis, systematic literature reviews and/or citation analyses [25,26].

Keeping in mind the need for conducting a comprehensive bibliometric study on green marketing, intended to fill this gap in marketing research, we have utilized a wide range of keywords (discussed in depth in the methodology section) in the bibliometric analysis. Unlike the previous bibliometric studies, the scope of this study has been extended to include all academic materials and resources (articles, conference papers, books, book chapters, etc.) published in all languages during the period of the study. The research considers both quantitative and qualitative dimensions of green marketing research by extracting not only the number of publications but also the data on citations as well as analysis of multiple factors such as authors, organizations, countries, keywords, sources and the annual productivity of papers.

The current study aims to evaluate and identify the publishing trends and patterns in green marketing from 1977 to 2020 by assessing the most productive countries, organiza- 
tions, and authors; key journals; authorship patterns; collaborative networks; three-factor analysis; and global collaboration patterns.

The following research questions have been formulated to achieve the objectives of the research:

1. What were the publishing trends in green marketing from 1977 to 2020 ?

2. Which journals have been frequently preferred by researchers for green marketing?

3. Which of the countries, organizations, and authors have been most productive in green marketing research?

4. Which authorship and collaborative patterns of research have been most common in green marketing research?

5. Which keywords have been frequently used in green marketing research?

\section{Methodology}

\subsection{Method}

The bibliometric analysis method was used to evaluate and identify the publishing trends and patterns in green marketing literature. Bibliometric is a quantitative/statistical method used to analyze publishing trends of research articles, conference papers, and other scholarly documents.

\subsection{Database Selection}

There are several renowned indexing and abstracting databases. Some are multidisciplinary (Scopus, WOS) while others are subject-specific databases (MEDLINE, PubMed, AGRICOLA, ERIC). Out of these databases, Scopus and WOS are both highly regarding all over the world. WOS was chosen for the purpose of this study as it is considered to be the most trusted, powerful, and reliable database in the world, and is guided by the legacy of Dr. Eugene Garfield, the inventor of the world's first citation index. The data were retrieved from the WOS authentic indexing and abstracting scientific database, containing quality academic work. Both the qualitative and quantitative aspects are covered in the current study. It is worth noting that some papers, which were indexed in other multidisciplinary and subject-specific databases, might have been missed during the process of data retrieval.

\subsection{Search Query}

The following search query was run in the topic field (TS) of the WOS core collection. The query was run on 19 June 2020, at Imam Abdulrehman Bin Faisal University, Saudi Arabia.

TS = ("Green marketing" OR "ecological marketing" OR "eco* marketing" OR "sustainable marketing" OR “Environmental Marketing" OR "Enviro* Marketing").

\subsection{Inclusion/Exclusion Criteria}

The time frame for the publication search was automatically set in WOS from 1900 till 19 July 2020, with no limitations on language and year of publication. Double-extraction method was used. Two authors extracted the data and evaluated the study eligibility independently. The titles and abstracts of all acceptable papers were individually screened. The search yielded 1198 results which were then imported into an excel file. Four duplicated records were removed and the rest were further screened for relevance by excluding 169 irrelevant records consisting of reviews, notes, editorial materials, letters, short surveys, meeting abstracts, news items, or corrections. A total of 1025 records were then assessed for eligibility. No irrelevant records were identified at this stage (Figure 1).

\subsection{Data Analysis}

Data analysis was performed using various tools and software including MS Excel (v16.0), VOS viewer (version 1.6.15), Biblioshiny (version 2.0), CiteSpace (version 5.7.R3), and ScientoPy (version 2.0.3.) 


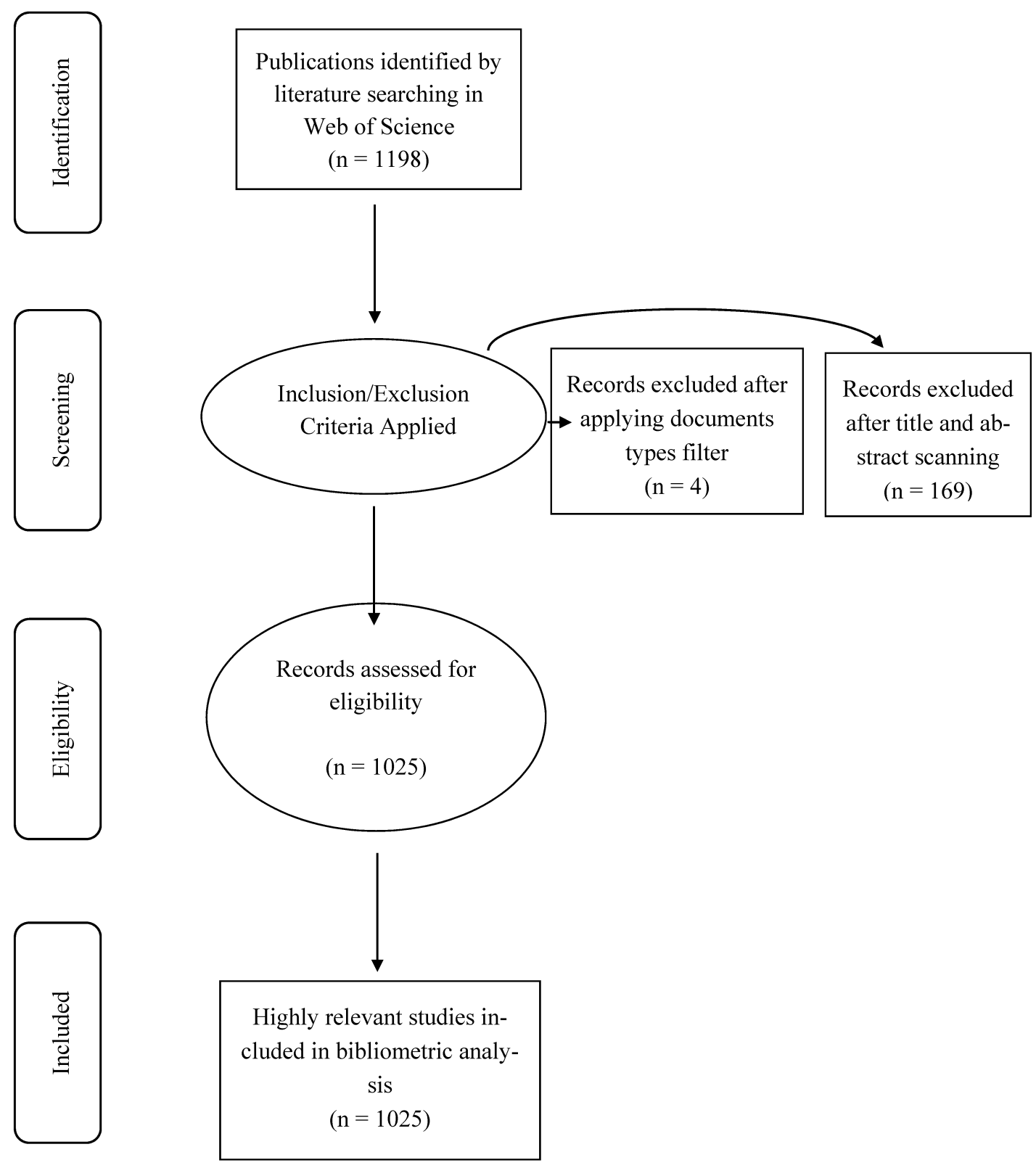

Figure 1. Four-phase flow chart of data extraction and filtration process.

\section{Data Analysis}

This section presents the results of the bibliometric analysis of green marketing literature published during the period of the study. After screening each record by reading the title and abstract, 1025 records consisting of articles, review papers, proceeding papers, early access, and book chapters were selected for data analysis. It was found that these records/articles had been published in 634 journals, written by 2218 authors, affiliated with 1106 institutions based in 84 countries. Furthermore, they had received 18,140 citations. A total of 1013 had been published in the English language while only 12 were in other languages. In the study, the citation impact (CI), which describes the average citations received by specific publications, was calculated by dividing the total number of citations by a total number of publications. The $\mathrm{CI}$ illustrates the average number of citations that a specific publication has received. Additionally, certain terms such as U1, U2, and Z9, as defined by the WOS database, were used [27]. U1 refers to the usage count of a publication in the last 180 days. Usage count is defined by the WOS as the count of the number of times the full text of a record has been accessed or saved in the last 180 days. This count can 
fluctuate as the end date of the fixed period advances and is updated daily [28]. Since the data were retrieved on 19 July 2020, it would be the reference start date for the last 180 days. Similarly, U2 refers to the usage count since 2013, and Z9 refers to the total times cited count (cited in the WOS Core Collection, Arabic Citation Index, BIOSIS Citation Index, Chinese Science Citation Database, Data Citation Index, Russian Science Citation Index, SciELO Citation Index).

\subsection{Analysis of the Overall Growth Trend}

Figure 2 shows the year-wise frequency of publications and citations of green marketing literature from 1977 to 2020 . Some years are missing as no publication was recorded in 1978, 1979, 1981-1983, 1985, 1987-1988, and 1990. The number of publications and citations have significantly increased over the years. A boom in citations and publications on green marketing can be observed after 2012 and 2019, respectively. The most successful publication year was 2019, in which the highest (118) number of articles were published. On the other hand, the highest number of citations (2062) were seen in the year 2012.

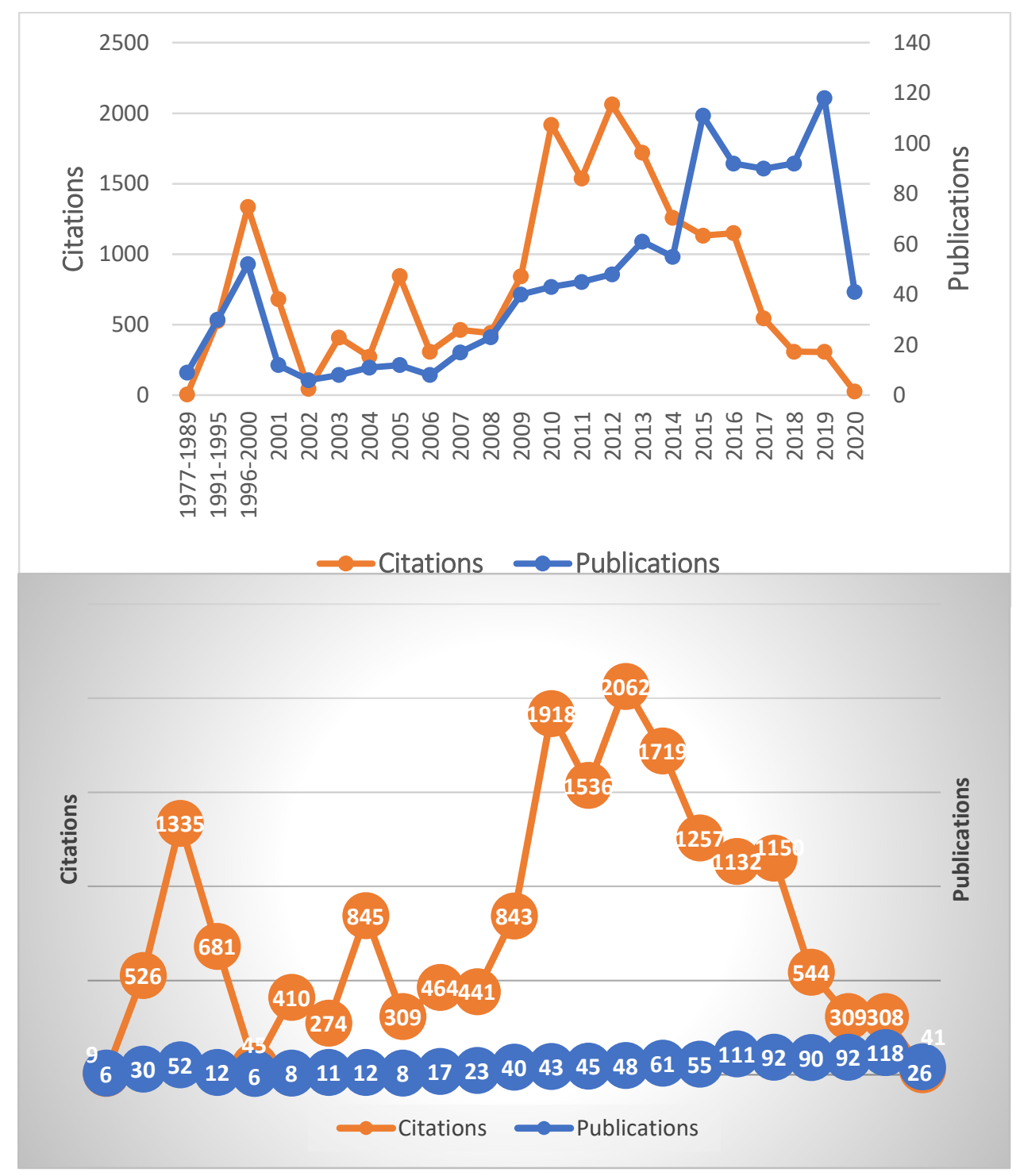

Figure 2. Publication and citations trend on green marketing research (1977-2020). 


\subsection{Top Ten Publishing Countries}

The top ten highly productive countries are shown in Table 1 . It can be seen that the most productive country had produced over 200 publications, the top two countries had over 140 publications, and the top five countries in the list have produced over 50 publications during the period of the study. The results show that the United States of America (USA) has had outstanding productivity with 201 publications and 7072 citations; followed by China with 146 publications and 1431 citations. However, the highest CI (50.52) was recorded for the United Kingdom (UK), despite having only 54 publications. Canada can be seen at the bottom of the list with only 27 publications.

Table 1. Top ten influential countries in Green Marketing Research (1977-2020).

\begin{tabular}{ccccc}
\hline Country & TP & Percent & TC & Citation Impact \\
\hline USA & 201 & 19.7 & 7072 & 35.18 \\
China & 146 & 14.3 & 1431 & 9.80 \\
UK & 54 & 5.3 & 2728 & 50.52 \\
Romania & 53 & 5.2 & 164 & 3.09 \\
India & 52 & 5.1 & 788 & 15.15 \\
Taiwan & 42 & 4.1 & 1572 & 37.43 \\
Australia & 38 & 3.7 & 704 & 18.53 \\
Malaysia & 33 & 3.2 & 192 & 5.82 \\
Brazil & 29 & 2.8 & 61 & 2.10 \\
Canada & 27 & 2.6 & 1089 & 40.33 \\
\hline
\end{tabular}

$\mathrm{TP}=$ total publication, $\mathrm{TC}=$ total citation.

Figure 3 highlights the top 10 countries and their contributions during the 2001-2020 period. Romania contributed the most after USA and China, while Germany had the least number of contributions during the time frame. The latest published data from 2019-2020 informed that the top three most productive countries were China, USA, and Malaysia (Figure 2).
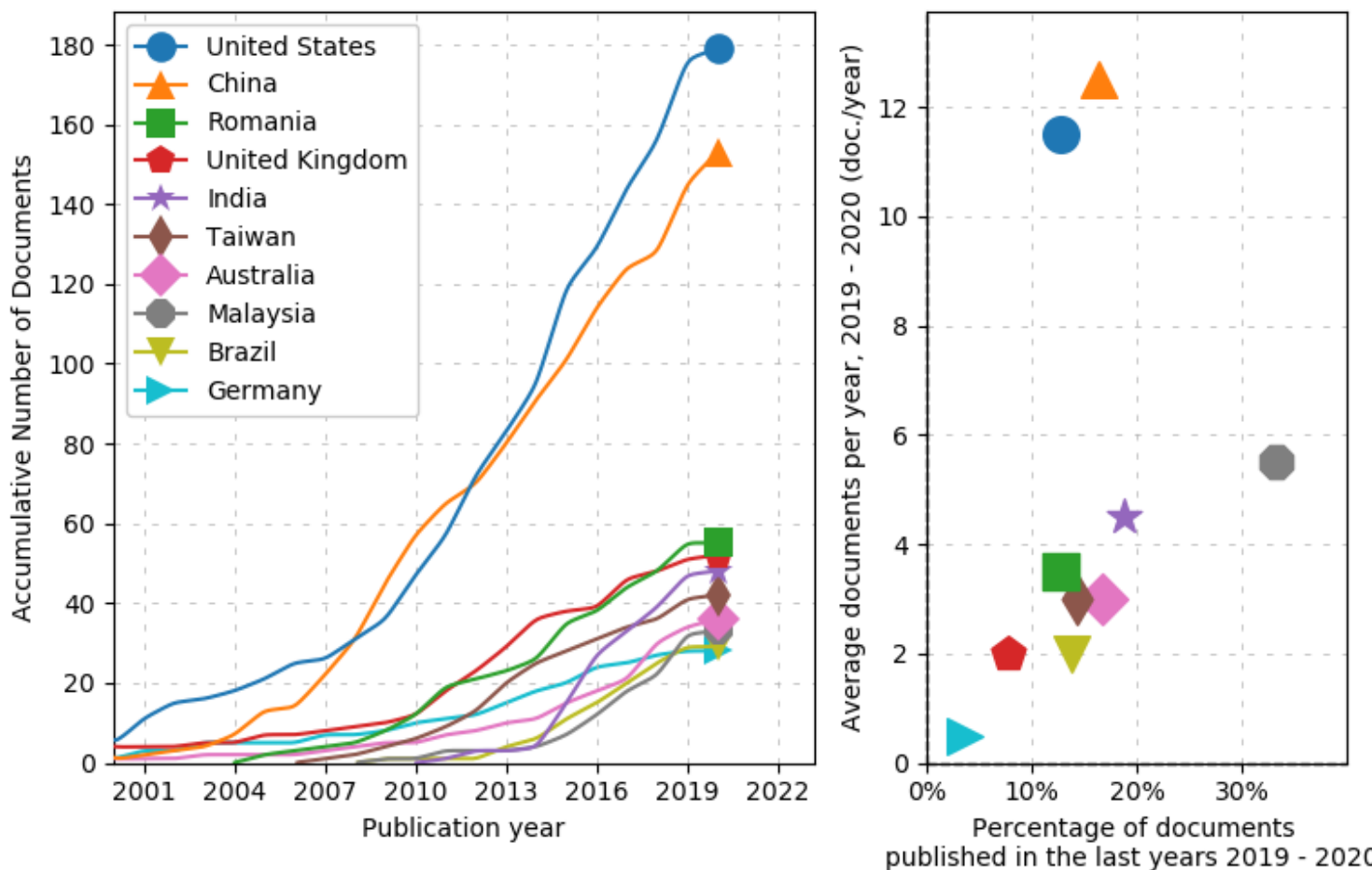

Figure 3. Top ten highest-publishing countries and their contribution. 


\subsection{Top Ten High-Research-Producing Institutions}

The top 10 research-producing organizations are shown in Table 2. It is apparent that most of the organizations $(n=6)$ had 8 or 9 publications, whereas the top 2 organizations had 12 and 10 publications, respectively. The Bucharest University of Economic Studies, Romania, emerged as the most productive organization with 12 publications and 32 citations, followed by the University of Leeds, England, with 10 publications, 649 citations, and a CI of 64.90. Tamkang University, Taiwan, had an impressive CI of 68.63 with only eight publications, while the same number of publications produced by The University Brawijaya, Indonesia, had the lowest CI of 1.13 with only nine citations.

Table 2. Top ten most highly productive organizations.

\begin{tabular}{cccc}
\hline Affiliations and Country & TP & TC & Citations Impact \\
\hline Bucharest University of Economic Studies, Romania & 12 & 32 & 2.67 \\
University of Leeds, England & 10 & 649 & 64.90 \\
National Taipei University, Taiwan & 9 & 586 & 65.11 \\
Penn State University, USA & 9 & 274 & 30.44 \\
University of Beira Interior, Portugal & 9 & 248 & 27.56 \\
Islamic Azad University, Iran & 8 & 23 & 2.88 \\
Tamkang University, Taiwan & 8 & 549 & 68.63 \\
University Brawijaya, Indonesia & 8 & 9 & 1.13 \\
Delft University Technology, Netherlands & 7 & 27 & 3.86 \\
Hong Kong Polytech University, Hong Kong & 7 & 296 & 42.29 \\
\hline
\end{tabular}

$\mathrm{TP}=$ total publication, $\mathrm{TC}=$ total citation.

\subsection{Most Prolific Authors}

Table 3 highlights the most prolific authors in green marketing literature. The study results showed that the publication range of authors varied from five to nine. "Chen YS" emerged as the most productive author with nine publications, 921 citations, and the highest h-Index, followed by "Kim J" with 7 publications (Table 3). Notably, four authors in the list had recently (2019) started contributing to the literature on green marketing and did not have any citations at the time of the study $(\mathrm{TC}=0)$.

Table 3. Authors Impact.

\begin{tabular}{cccccc}
\hline Author & Affiliations and Country & TP & TC & FY of Publication & H_Index \\
\hline Chen YS & The National Yunlin University of Science & 9 & 921 & 2010 & 8 \\
and Technology and Taiwan & University of Illinois and USA & 7 & 67 & 2014 & 4 \\
Kim J & University of Beira Interior and Portugal & 6 & 96 & 2010 & 5 \\
Leonidou CN & University of Leeds and UK & 6 & 472 & 2011 & 6 \\
Leonidou LC & University of Cyprus and Cyprus & 6 & 394 & 011 & 0 \\
Amaliana L & Universitas Brawijaya and Indonesia & 5 & 0 & 2019 & 0 \\
Astuti AB & Universitas Brawijaya and Indonesia & 5 & 0 & 5 & 2012 \\
Chang CH & Tamkang University and Taiwan & 5 & 515 & 019 & 0 \\
Darmanto & Universitas Brawijaya and Indonesia & 5 & 0 & 019 & 0 \\
Fernandes AAR & Universitas Brawijaya and Indonesia & 5 & 0 & 2019 \\
\hline
\end{tabular}

FY for the first year of publication on this specific topic/area; TP = total publication, $\mathrm{TC}=$ total citation.

\subsection{Top Ten Influential Research Journals}

Table 4 highlights the top 10 research journals in green marketing literature. It shows that five journals had more than 10 publications. Seven out of the 10 top journals fell under the Quartile 1 category and the maximum number of journals (4) had been published from Netherlands. The journal "Sustainability" (MDPI) stands first in the table with 33 publications and 149 citations, followed by the Journal of Cleaner Production (Elsevier) with 22 publications and 746 citations. It is interesting to note that the "Journal of the Academy 
of Marketing Science", which has published only nine publications, had 907 citations and the highest impact factor of 9.36 .

Table 4. Source Impact.

\begin{tabular}{|c|c|c|c|c|c|c|}
\hline Source & TP & TC & IF & Q & Publisher & Country \\
\hline Sustainability & 33 & 149 & 2.59 & 2 & MDPI & Switzerland \\
\hline Journal of Cleaner Production & 22 & 746 & 6.40 & 1 & Elsevier & Netherlands \\
\hline Journal of Business Ethics & 18 & 1359 & 3.80 & 1 & Springer & Netherlands \\
\hline Journal of Business Research & 18 & 1121 & 4.03 & 1 & Elsevier & Netherlands \\
\hline Industrial Marketing Management & 14 & 714 & 4.78 & 1 & Elsevier & Netherlands \\
\hline Amfiteatru Economic & 10 & 104 & 1.24 & 4 & Editura ASE Bucuresti & Romania \\
\hline Business Strategy and The Environment & 10 & 436 & 6.38 & 1 & John Wiley and Sons & United States \\
\hline International Journal of Consumer Studies & 10 & 274 & 1.51 & 4 & Wiley-Blackwell Publishing & United Kingdom \\
\hline Journal of Marketing & 9 & 636 & 7.82 & 1 & American Marketing Association & United States \\
\hline Journal of The Academy of Marketing Science & 9 & 907 & 9.36 & 1 & Springer & United States \\
\hline
\end{tabular}

IF for impact factor, Q for Journal Quartile.

\subsection{Most Cited Journals with Strongest Citation Burst}

A citation burst is a useful analytic method used to identify articles that receive particular attention from relevant scientific communities during a certain time frame [29]. In other ways, it highlights the most active period of a document during which it garners maximum attention from the scientific community. Figure 4 represents the top 10 most cited journals with maximum citation bursts using CiteSpace software. The blue color represents the overall time period of the citation burst and red color represents the active time period of citation burst. It can be seen that three journals had a strength of seven or more based on their citation bursts. "Environment Marketing Strategy" (sr. no. 10) had the highest strength of 7.64 from 1996 to 2012 followed by "American Economy Review" (sr. no. 4) with a strength of 7.26 from 1994 to 2011. The oldest and the latest citation bursts were noticed for the "Journal of Public Policy \& Marketing" (sr. no. 8) with the lowest strength of 3.82 from 1995 to 1998 and the "American Sociological Review" (sr. no. 2) with a strength of 5.60 from 1991 to 2011, respectively.

\begin{tabular}{|l|r|r|r|r|l|}
\hline \multicolumn{1}{|c|}{ Cited Journals } & Year & Strength & Begin & End & 1991 - 2020 \\
\hline 1 ADMIN SCI QUART & 1991 & 4.5666 & $\mathbf{1 9 9 1}$ & 2011 & \\
\hline 2 AM SOCIOL REV & 1991 & 5.6002 & $\mathbf{1 9 9 1}$ & 2014 & \\
\hline 3 J POLIT ECON & 1991 & 4.4821 & $\mathbf{1 9 9 2}$ & 2013 & \\
\hline 4 AM ECON REV & 1991 & 7.2647 & $\mathbf{1 9 9 4}$ & 2011 & \\
\hline 5 FOREST PROD J & 1991 & 3.8072 & $\mathbf{1 9 9 4}$ & 2011 & \\
\hline 6 ECOLOGICAL MARKETING & 1991 & 5.3799 & $\mathbf{1 9 9 5}$ & 2011 & \\
\hline 7 ADVERTISING AGE & 1991 & 5.8016 & $\mathbf{1 9 9 5}$ & 2013 & \\
\hline 8 J PUBLIC POLICY MARK & 1991 & 3.8261 & $\mathbf{1 9 9 5}$ & 1998 & \\
\hline 9 ENV MARKETING POSITI & 1991 & 7.1411 & $\mathbf{1 9 9 6}$ & 2011 \\
\hline 10 ENV MARKETING STRATE & 1991 & 7.6488 & $\mathbf{1 9 9 6}$ & 2012 \\
\hline
\end{tabular}

Figure 4. Top 10 cited journals with the strongest citation bursts. 


\subsection{Authorship Pattern}

Figure 5 displays the authorship patterns in green marketing literature. It was found that the authorship pattern ranged from single author to a maximum of 13 authors. This shows that collaborative research is far more common than single authorship in green marketing literature (two and three authors). The top three authorship patterns included two authors with 334 publications, three authors with 257 publications, and single author with 241 publications.

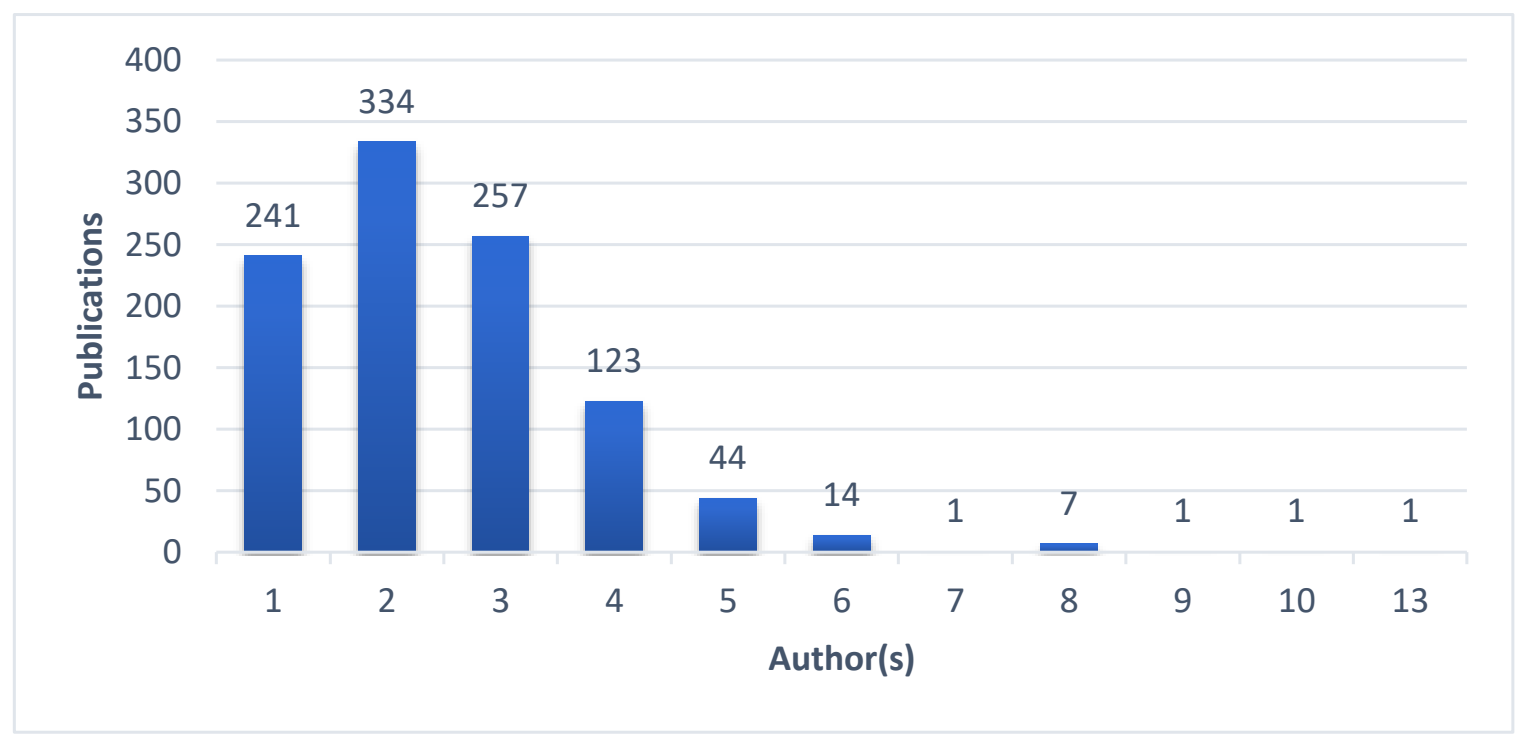

Figure 5. Authorship pattern of green marketing researchers.

\subsection{Keyword Analysis}

A keyword analysis of the data informed us that 2346 different keywords had been used by green marketing authors during their research. A co-occurrence network of keywords had been used with a minimum occurrence of seven keywords and 54 items containing eight clusters, as shown in Figure 6. The size of the ball shows a strong network of keywords and each color represents a separate cluster. It was observed that the top five keywords, i.e., green marketing, sustainability, sustainable development, environment, and sustainable marketing, had a significant number of occurrences and this was evident in the total link strength.

Figure 7 shows the top 15 keywords used in green marketing research from 2001 to 2020. The figure has two distinct panels. The left keywords panel highlights data from 2001 to 2020, and the right panel covers keywords from 2016 to 2020. Both panels show that "green marketing" and "sustainability" were the prevailing topics in all green marketing areas of research. Furthermore, the right panel shows that the top five sub-areas from 2016 to 2020 were "green marketing", with 32 publications, followed by "sustainability" with 11 publications, "sustainable development" and "sustainable marketing" with 5 publications each, and "environmental marketing" with only three publications. Additionally, if we compare Figures 5 and 6, it becomes apparent that some new sub-areas of green marketing have appeared in the 21st century. For instance, the keyword "environment" on the fourth rank in Figure 5 is replaced by "sustainable marketing" in Figure 6. 


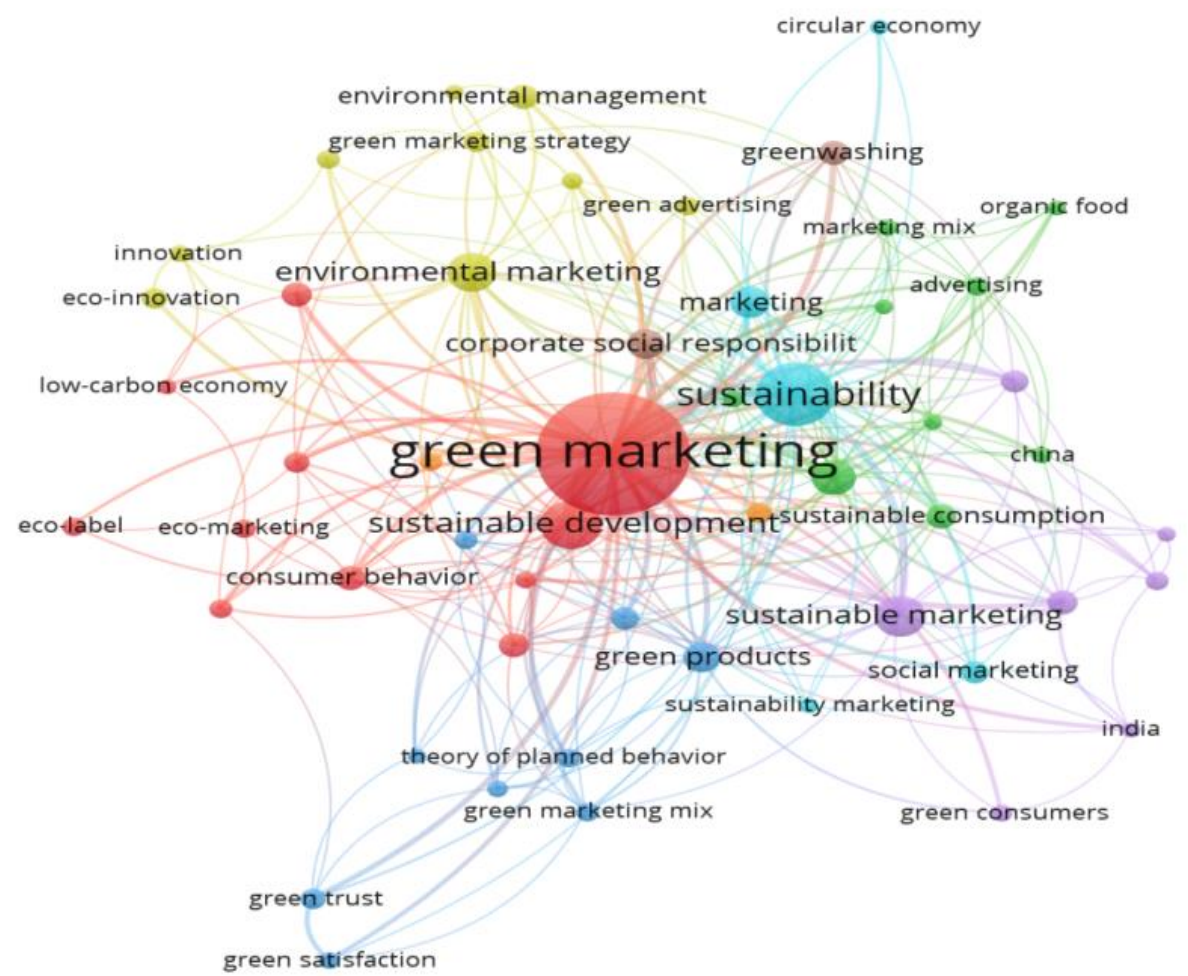

Figure 6. Co-occurrence network of author keywords (minimum number of occurrences: seven).
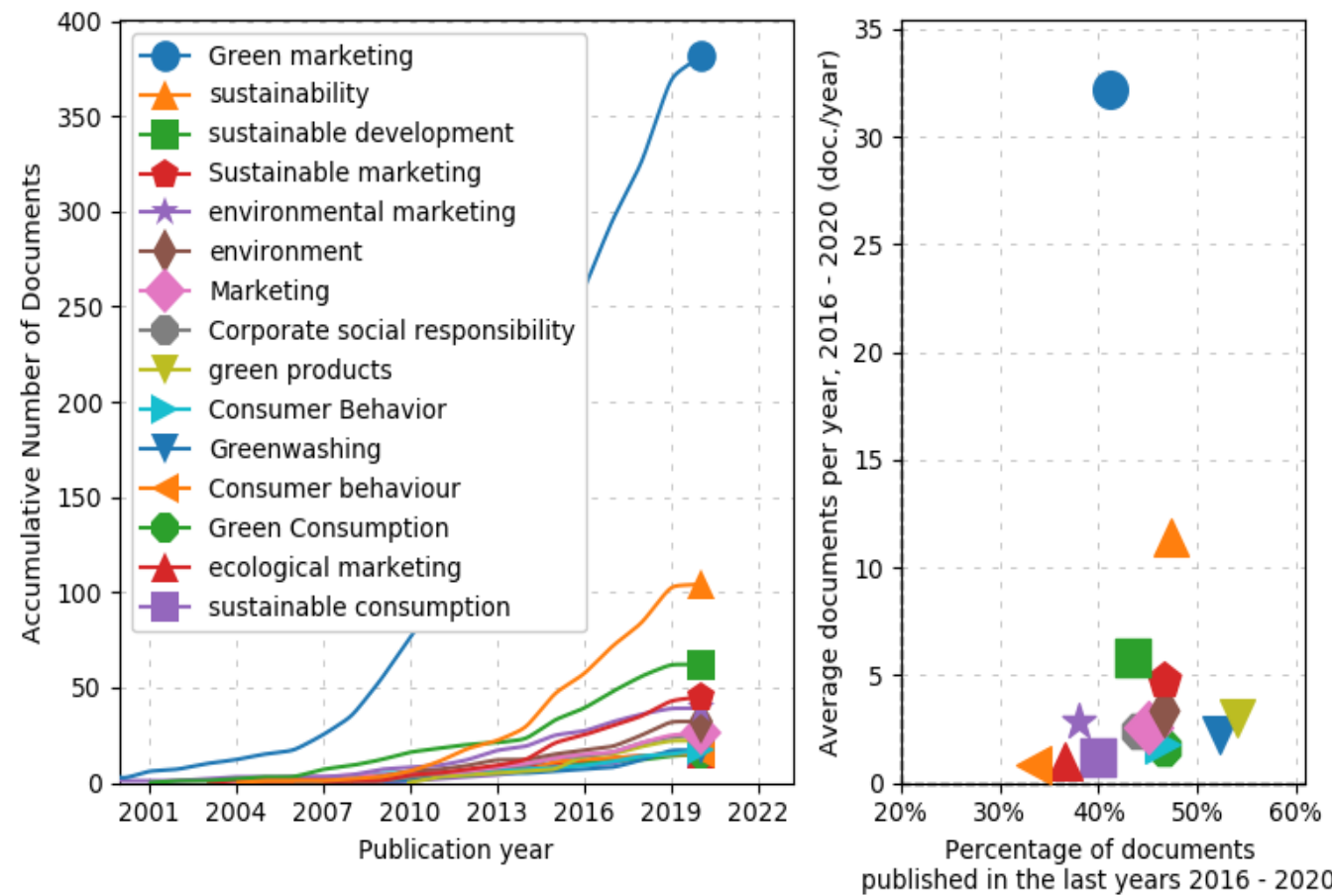

Figure 7. Author keyword analysis between the years 2001-2020.

\subsection{Highly Cited Articles on Green Marketing}

Table 5 highlights the top 10 most cited articles on green marketing. All of the articles in this list had over 200 citations and their publications range varied between 1995 and 2012. The results also show that the article entitled "Green Supply Chain Management in China: Pressures, Practices and Performance" by Zhu, Sarkis, and Geng, published in 
International Journal of Operations \& Production Management in the year 2005 was the top performing publication with 568 citations, 22 U1 usage, 306 U2 usage and 589 Z9 score. This was followed by articles written by Miles and Covin (2000) with 357 citations, and Luchs, Naylor, Irwin, and Raghunathan (2010) with 339 citations. It is worth mentioning that the article entitled "The Drivers of Greenwashing" by Delmas and Burbano (2011) had only 296 citations but had the highest U1 score of 51 and a significant U2 score of 297. Lastly, the article "Consumer Attitude and Purchase Intention Toward Green Energy Brands: The Roles of Psychological Benefits and Environmental Concern" had 248 citations.

Table 5. Top ten most cited articles on green marketing.

\begin{tabular}{|c|c|c|c|c|c|c|c|}
\hline Title & Author & Journal & Year & TC & U1 & U2 & Z9 \\
\hline $\begin{array}{c}\text { Green Supply Chain Management in } \\
\text { China: Pressures, Practices, and } \\
\text { Performance }\end{array}$ & $\begin{array}{l}\text { Zhu, Q., Sarkis, J., and } \\
\text { Geng, Y. }\end{array}$ & $\begin{array}{l}\text { International Journal of } \\
\text { Operations E Production } \\
\text { Management }\end{array}$ & 2005 & 568 & 22 & 306 & 589 \\
\hline $\begin{array}{c}\text { Environmental Marketing: A Source } \\
\text { of Reputational, Competitive, And } \\
\text { Financial Advantage }\end{array}$ & $\begin{array}{l}\text { Miles, M.P., and } \\
\text { Covin, J.G. }\end{array}$ & Journal of Business Ethics & 2000 & 357 & 5 & 83 & 369 \\
\hline $\begin{array}{c}\text { The Sustainability Liability: Potential } \\
\text { Negative Effects of Ethicality on } \\
\text { Product Preference }\end{array}$ & $\begin{array}{l}\text { Luchs, M.G., Naylor, R.W., } \\
\text { Irwin, J.R., and } \\
\text { Raghunathan, R. }\end{array}$ & Journal of Marketing & 2010 & 339 & 20 & 245 & 341 \\
\hline $\begin{array}{c}\text { The Drivers of Green Brand Equity: } \\
\text { Green Brand Image, Green } \\
\text { Satisfaction, And Green Trust }\end{array}$ & Chen, Y.S. & Journal of Business Ethics & 2010 & 335 & 30 & 210 & 338 \\
\hline The Drivers of Greenwashing & $\begin{array}{l}\text { Delmas, M.A., and } \\
\text { Burbano, V.C. }\end{array}$ & California Management Review & 2011 & 295 & 51 & 297 & 296 \\
\hline $\begin{array}{l}\text { Us Consumers' Willingness to Pay for } \\
\text { Green Electricity }\end{array}$ & $\begin{array}{c}\text { Roe, B., Teisl, M.F., } \\
\text { Levy, A., and Russell, M. }\end{array}$ & Energy Policy & 2001 & 279 & 4 & 90 & 281 \\
\hline $\begin{array}{l}\text { Environmental Management of a } \\
\text { Tourist Destination-A Factor of } \\
\text { Tourism Competitiveness }\end{array}$ & Mihalic, T. & Tourism Management & 2000 & 272 & 3 & 110 & 287 \\
\hline $\begin{array}{l}\text { Buyer Characteristics of The Green } \\
\text { Consumer and Their Implications for } \\
\text { Advertising Strategy }\end{array}$ & $\begin{array}{l}\text { Shrum, L.J., McCarty, J.A., } \\
\text { and Lowrey, T.M. }\end{array}$ & Journal of Advertising & 1995 & 256 & 10 & 113 & 260 \\
\hline $\begin{array}{c}\text { Design for The Environment: A } \\
\text { Quality-Based Model for Green } \\
\text { Product Development }\end{array}$ & Chen, C.1. & Management Science & 2001 & 250 & 20 & 165 & 258 \\
\hline $\begin{array}{l}\text { Consumer Attitude and Purchase } \\
\text { Intention Toward Green Energy } \\
\text { Brands: The Roles of Psychological } \\
\text { Benefits and Environmental Concern }\end{array}$ & $\begin{array}{l}\text { Hartmann, P., and } \\
\text { Apaolaza-Ibáñez, V. }\end{array}$ & Journal of Business Research & 2012 & 248 & 19 & 262 & 253 \\
\hline
\end{tabular}

\subsection{Three-Factor Analysis}

3.10.1. Keywords, Authors and Sources

Figure 8 presents the published literature on green marketing by focusing on the relationship among top keywords, authors, and sources. The results of the analysis identified the top authors in green marketing, preferred source for publications, and sub-areas of green marketing. Figure 8 shows that the top three authors, i.e., Chen YS., Kim J., and Do Pace A., and five sub-areas, i.e., green marketing, green, sustainability, environmental marketing, and marketing, had a strong relationship with green marketing itself. Furthermore, these authors preferred to publish in three sources, i.e., Journal of Business Ethics, Journal of Cleaner Production, and Journal of Global Scholars of Marketing Science. 


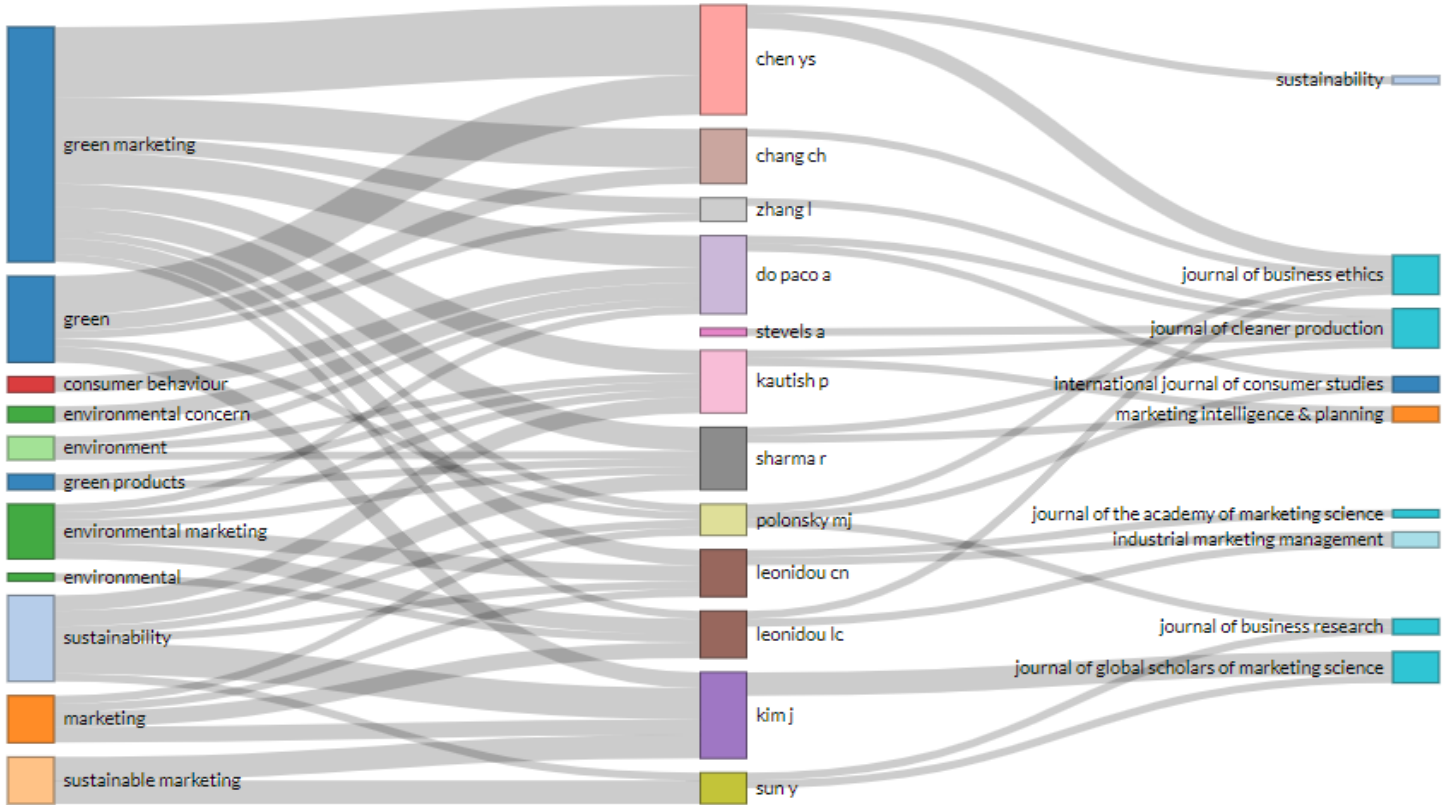

Figure 8. Three-factor analysis of the relationship among keywords (left), authors (center), and sources (right).

\subsubsection{Keywords, Sources and Countries}

Figure 9 shows the relationship among subject areas (keywords), sources, and countries on green marketing research. The top five subject areas, i.e., green marketing, sustainability, green, marketing, and sustainable marketing, had a relationship with five sources, i.e., Sustainability, Journal of Business Research, Journal of Cleaner Production, Journal of Business Ethics, and Business Strategy and The Environment. Furthermore, these subject areas had a strong relationship with the top two most productive countries, i.e., USA and China.

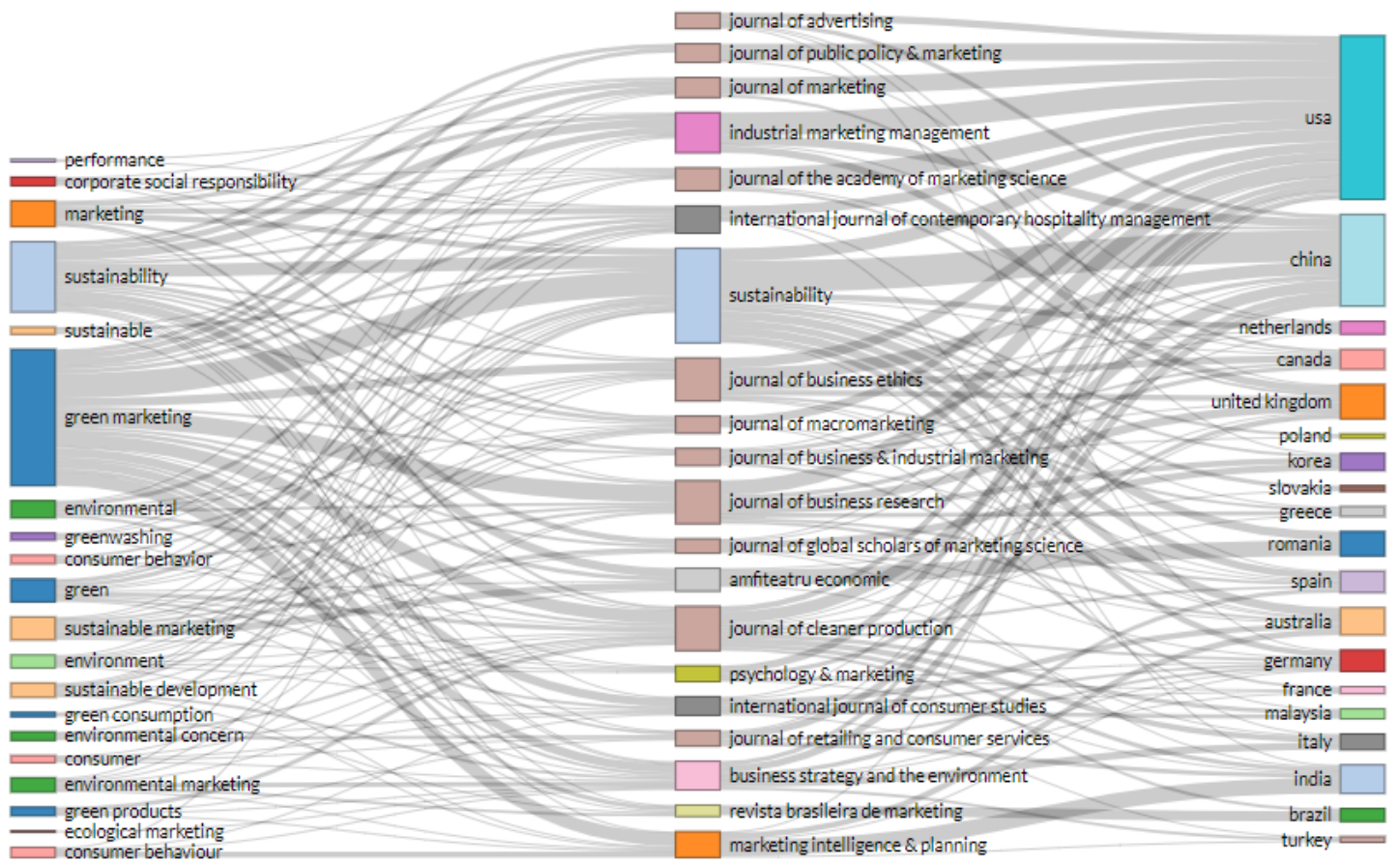

Figure 9. Three-factor analysis of the relationship among keywords (left) sources (middle) and countries (right). 


\subsection{Country Collaboration Map on Green Marketing Research}

Figure 10 shows the country collaboration map on green marketing literature. USA emerged as top collaborator with China (12 publications), followed by Canada and Korea (eight publications each), and India with the USA (six publications). There were six collaborations between UK and Cyprus. The least active among the 25 collaborators were Germany and Norway with only two publications.

\section{Country Collaboration Map}

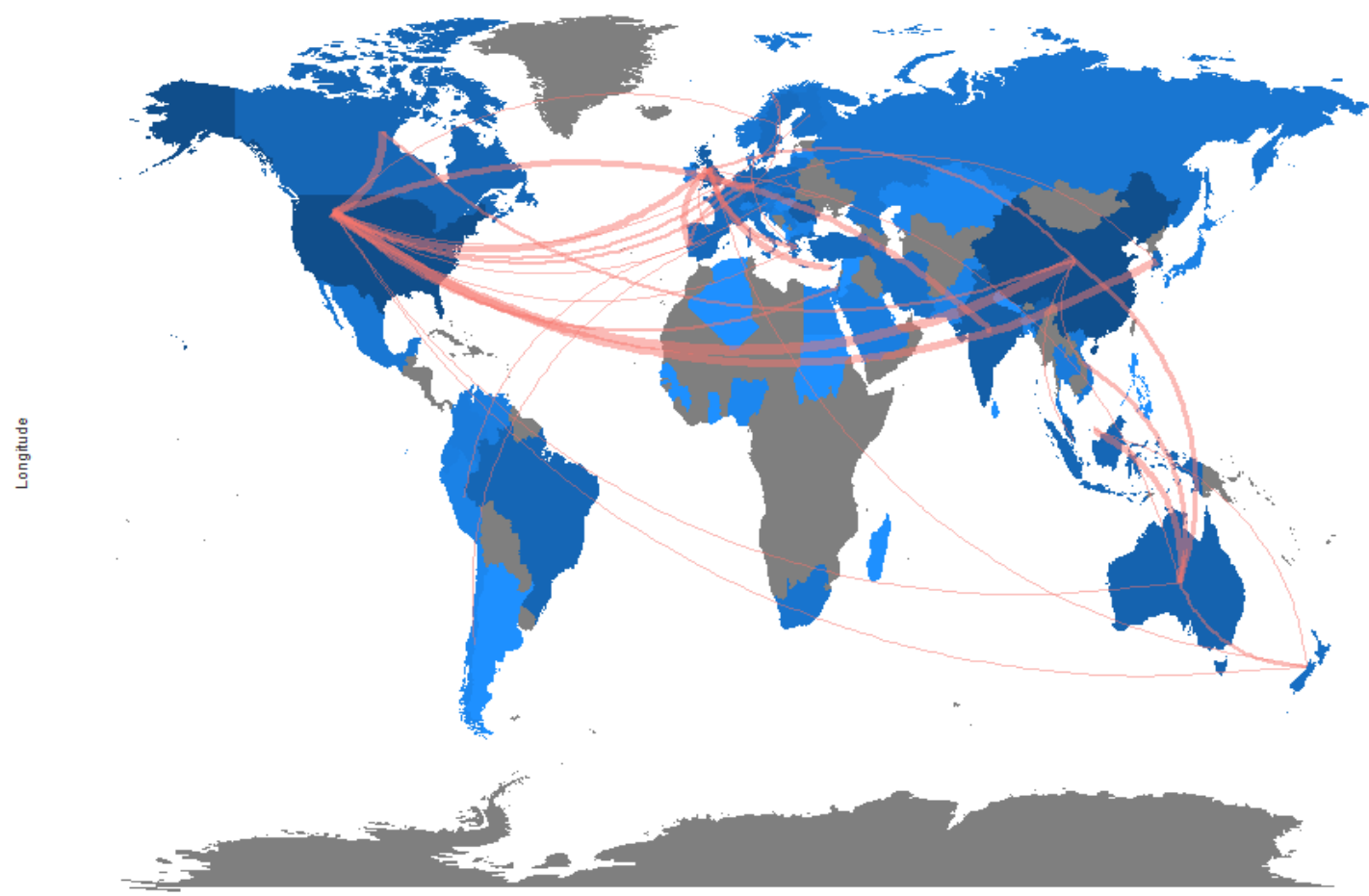

Latitude

Figure 10. Country collaboration map on green marketing literature.

\subsection{Citation Bursts of Green Marketing Literature}

Citation bursts present evidence that a specific publication is connected with a citation boom in a specific timeframe. Figure 11 presents the cited bursts of green marketing literature using CiteSpace software. The blue color represents the overall time period of the citation burst, light-blue color represents the citation bursts started after the year 2000 and red color represents the active time period of citation burst. The highest bursts were observed on the first (8) references with strengths over 5.0. The reference on the top with the highest strength was written by Peattie K (9.37) in the 2003-2013 period, followed by Ottman JA (6.53) in 2003-2010, Coddington W (6.25) in 2000-2011, Carlson L (6.06) in 2010-2014, Kinnear TC (5.82) in 2009-2012, Apeldoorn Paul C (5.39) in 2009-2012, Banerjee SB (5.17) in 2009-2014 and Henion KE (5.16) in the 2010-2011 period. It is interesting to note that the reference Henion KE had gained significant strength/boom in a limited amount of time (2010-2011). Further, the latest bursts of 2 references that remained until 2015, were those of Porter ME (strength: 4.46) and Cleveland M (strength: 3.90), respectively. 


\section{Top 20 References with the Strongest Citation Bursts}

\begin{tabular}{|c|c|c|c|}
\hline References & Year $\mathrm{S}$ & trength Begin End & $2000-2020$ \\
\hline Peattie K, 1995, ENV MARKETING MANAGE, V0, P0 & 1995 & 9.375620032013 & \\
\hline Ottman JA, 1998, GREEN MARKETING OPPO, V0, P0 & 1998 & 6.531420032010 & \\
\hline Coddington W, 1993, ENV MARKETING POSITI, V0, P0 & 1993 & 6.255920002011 & \\
\hline CARLSONL, 1993, J ADVERTISING, V22, P27, DOI & 1993 & 6.063720102014 & \\
\hline KINNEAR TC, 1974, J MARKEIING, V38, P20, DOI & 1974 & 5.828120092012 & \\
\hline Apeldoorn Paul C, 1996, J MACROMARKETING, V16, P45, DOI & 1996 & 5.39520092012 & \\
\hline Banerjee SB, 2002, J BUS RES, V55, P177, DOI & 2002 & 5.176820092014 & \\
\hline Henion KE, 1976, ECOLOGICAL MARKETING, V0, P0 & 1976 & 5.161620102011 & \\
\hline Menon A, 1997, J MARKETING, V61, P51, DOI & 1997 & 4.850920092012 & \\
\hline KASSARJAN HH, 1971, J MARKETING, V35, P61, DO] & 1971 & 4.698920092012 & \\
\hline Fuller DA, 1999, SUSTAINABLE MARKETIN, V0, P0 & 1999 & 4.595620092011 & \\
\hline PORTER ME, 1995, HARVARD BUS REV, V73, P120 & 1995 & 4.468320092015 & \\
\hline Crane A, 2000, J STRATEGIC MARKETIN, V8, P277, DOI & 2000 & 3.963820092011 & \\
\hline Cleveland M, 2005, J CONSUM MARK, V22, P198, DOI & 2005 & 3.907520092015 & \\
\hline ARMSTRONG JS, 1977, J MARKETING RES, V14, P396, DOI & 1977 & 3.836620032013 & \\
\hline SHRIVASTAVA P, 1995, STRATEGIC MANAGE J, V16, P183, DOI & 1995 & 3.598620092013 & \\
\hline ELLEN PS, 1991, J PUBLIC POLICY MARK, V10, P102, DOI & 1991 & 3.461620102013 & \\
\hline
\end{tabular}

Figure 11. Citation bursts of articles (2000-2020).

\section{Discussions}

\subsection{Most Productive Countries, Authors, and Institutions and Publishing Trends}

The results of the study show that the total number of publications from the top 10 most productive countries accounted for $65.9 \%$ of the total investigated publications on green marketing. These findings reflect the high interest of certain countries in green marketing research. Among them, USA had the maximum number of publications (201), and UK had the most influential publications $(\mathrm{CI}=50.52)$. However, both the most productive institution and the most prolific author with the highest academic influence were surprisingly neither American nor British. Furthermore, even though USA had the highest number of total citations (TC $=7072$ ), the CI of the country's publications was less than those of UK, Canada, and even Taiwan. One of the most interesting findings of the study is related to the top 10 productive organizations. It was found that only two institutions from Taiwan accounted for a collective CI of 133.74, and each institution had received more than 500 citations.

A growing interest was also found among academics regarding green marketing research. The number of published articles has been progressively increasing over the years, with a sharp increase in the last decade. Highest number of articles were published in the year 2019. This increase is consistent with the global trend in both corporate social responsibility (CSR) and sustainability research [30,31]. Typically, most of the influential articles were published between 2001 and 2012 [32-34]. Furthermore, during the last two decades, the literature on green marketing has extensively increased in terms of both knowledge creation and diversity in themes [35].

There has been a growing interest in social and environmental research over the past decade in the context of the developing countries as well [36]. Consequently, there has been an increase in the number of researchers and academicians working in the environmental related fields in these emerging and developing economies. Globalizations and the interconnectedness of international markets have also necessitated the establishment of regulatory frame works to oversee the actions of manufacturers and marketers working in these emerging economies, and to ensure their adherence to international guidelines. 
Developing countries are the main suppliers and manufacturers of goods for the consumers in the developed world where social and environmental legal infrastructures are more robust; therefore, these manufacturers are compelled to adhere to policies set forth by the developed countries [37]. Compliance with local and international government regulations and industry standards has been the driving force behind the implementation of the environmental management systems in corporations working the developing world [38,39]. As a result of these social and environmental changes at the industrial and corporate levels, research related to social and environmental areas has also started gaining popularity among researchers in these emerging economies. The study results show that in the list of top 10 influential countries, six were developing or emerging economies, and three were from the Brazil, Russia, India, and China (BRIC) block. Seven out of 10 highly productive institutions were also from emerging economies and the first and third most influential authors also belonged to countries considered to be emerging economies.

Research on green marketing emerging from these developing economies also reflects the governmental interest towards sustainability. This is also in line with the sustainable development goals set forth by the United Nations (UN) in 2015 [40,41]. The environmental preservation is one of the major goals to be achieved by all nations as a long-term sustainability agenda laid out by the UN, along with certain economic and social factors [40]. Governmental funds, internal funding system of educational institutes, the corporate sector, and NGOs are the major funding sources for academic research in these countries [42] and, despite being independent, these funding bodies manage to work in close collaboration with each other on sustainability research. However, more work is needed in this regard, while Taiwan has managed to have a CI greater than that of USA, the rest of the five emerging economies (except India) had CI less than 10. The academic influence of these emerging economies (except Taiwan) is still weak. This might be due to the lack of international collaborations and/or the unavailability of the manuscripts.

\subsection{Influential Journals in Green Marketing}

Seven out of the 10 most preferred publication outlets for green marketing research are listed in the Quartile 1 (Q1) ranking of SSCI (Web of Science), four of these are from the Netherlands, and three are from USA. The Journal of Cleaner Production is ranked second with 22 articles and 746 total citations. Similarly, the Journal of Marketing has published 9 articles and is 2nd last in the list of highly influential journals. One out of those nine articles is ranked 3rd in the 10 most cited articles on green marketing [43]. Similarly, the Journal of Business Ethics has two highly cited articles on green marketing and is ranked third in the most influential journals with 18 articles, and the highest number of total citations. The Journal of Business Research is ranked fourth in the highly influential journals list and also has 1 article in the most cited article list. All these journals are from developed countries, follow a rigorous peer-review process and publish articles only in the English language. Secondly, the Journal of Marketing, Journal of Business Ethics, and Journal of Business Research are all specialized journals from the business category.

\subsection{Authorship, Collaborative Patterns and, Frequently Used Keywords}

Around $81.25 \%$ of the publications had three or fewer authors, and $23.5 \%$ were written by a single author. It should be noted that three of the 10 most influential articles were authored by one individual, three had two authors and two had four authors. Most collaborations were noted between the USA and China, and interestingly these two countries were one of the most influential countries in green marketing research as well. All top collaborations with developing countries including China, India, Cyprus, and Korea, were from USA.

International green marketing research collaborations are of paramount importance for all concerned. These collaborations help the collaborators in accessing technologies, knowledge, and resources, otherwise unavailable to them. They are also efficient and cost effective [44]. International collaborations help researchers maximize their citations [45]. 
According to the Royal Society, the articles with co-authors from five additional countries (in addition to the first author's country) received twice as many citations as compared to articles with no international collaborations [46]. The results of our analysis also support these findings.

The analysis identified top five keywords as "green marketing", "sustainability", "sustainable development", "environment", and "sustainable marketing". These keywords truly depict the essence of green marketing research. "Green consumerism", "green marketing mix", "green satisfaction", "consumer attitudes", and "green competitive advantage" were less researched keywords and represent the less considered sub-areas of green marketing. It has been observed that green consumerism, green satisfaction and green attitudes of consumers would need more attention in the future. The three-factor analysis of keywords, authors, and journals also identified the need for further investigating consumer behavior, environmental concerns, and green products.

\subsection{Citations Bursts and Three-Factor Keywords Analysis}

The papers that were highly cited were from varied journals such as the Journal of Marketing, Journal of Advertising, Journal of Business Ethics, Journal of Business Research, California Management Review, Management Science, Tourism Management, and International Journal of Operations and Production Management, and were published between 1995 and 2012. This finding indicates that seminal work was done on green marketing during this period. Henion's book "Ecological Marketing" received a significant number of citations in 2010-2011 [47]. Likewise, the highest citation burst was for Peattie's book "Environmental Marketing Management: Meeting the Green Challenge" from 20032013 [48]. In the results, top citation bursts started from 2000 and ended in 2015. These citation busts for green marketing literature identify its importance in the early 2000s, even though researchers were publishing in the area as early as 1971.

In the keywords analysis, it was found that authors from the USA and China had significantly used green marketing, sustainable marketing, and sustainability as keywords and had published in ISI impact factor journals including Sustainability, Journal of Business Research, Journal of Cleaner Production, Journal of Business Ethics, and Business Strategy and the Environment. All of these journals are highly respectable in the field of sustainability and green research. This finding highlights the importance of green marketing among authors, as well as editors of high impact journals, as an area of investigation. Researchers working in the green marketing area could focus on these journals as a possible outlet for their publications in the future. Similarly, our analysis also found greenwashing, ecological marketing, and sustainable consumption as promising emerging research areas for new researchers.

\subsection{Limitations and Future Research Directions}

Like all other bibliometric analysis studies, this study also had some limitations. Firstly, the analyzed data in the current study were downloaded only from WOS Core Collection database on a specific date; therefore, data from other databases collected at different times could have different results and conclusions [49]. Due to the WOS Core Collection database being the most authentic data source, we only focused on articles, conference papers, book chapters from WOS. Other databases may be incorporated (i.e., Scopus) to extend this work for a better understanding of research in green marketing. While the researchers endeavored to include all possible key terms to search and shortlist the articles for the study, however, the analysis could be extended by including more search terms as identified in the keywords cluster given in Figure 6.

Besides these limitations, the current investigation offers several prospective opportunities for future research. With this study, researchers from the green marketing area can design strategies focused on the topics (as shown by the visualization of data in this study) that are developing and have gained little attention in the previous investigations. In addition, they can find the most influential papers, authors, and journals to identify 
the research gaps and new insights in this area. Multiple avenues are possible for future research: future focus on more narrowed areas, i.e., green consumerism, green marketing mix, green satisfaction, consumer green attitudes, etc.; $4 \mathrm{Ps}$ (product, price, place, promotion) of green marketing can be investigated from a B to B and B to C market perspective; comparative research on green consumerism from developed and developing countries; and use of more comprehensive and broader demographic and psychographic variables. There are five notable predictions and trends that emerge from this study: research from developing and emerging economies; greenwashing; green consumerism; low-carbon economy; and eco-innovation.

\section{Conclusions}

The overall purpose of this study was to provide a comprehensive review of the research published on green marketing. Green marketing research is critical to promote sustainable consumerism in developed and developing countries. However, not a single bibliometric analysis has been completed that holistically reviews and summarizing the literature, progress, and future directions of this important sub-area of marketing as this study does for the period from 1977 to 2020.

Even so, based on our review and findings of the current study, we would like to suggest several prospective opportunities for future research. With this study, researchers working in the green marketing area can design strategies focused on the topics (as shown by the visualization of data in this study) that are developing. In addition, they can identify the most influential papers published, authors and journals in this area for identification of research gaps and new insights. For green marketing research trends and about the future insights, here are five notable predictions and trends from this study: research from developing and emerging economies; green washing; green consumerism; low-carbon economy; and eco-innovation. Similarly, based on the results of this bibliometric analysis, we can suggest the Journal of Marketing, Journal of Advertising, Journal of Business Ethics, Journal of Business Research, California Management Review, Management Science, Tourism Management, International Journal of Operations \& Production Management and Sustainability as possible outlets of scholarly work in green marketing.

To conclude, this research has made an important contribution to the growing body of knowledge on green marketing research. By analyzing 1025 published articles, conference papers, and book chapters from WOS, we have provided new insights in the green marketing research area. Another important contribution of the current study is the inclusion of articles written in all languages. Results have shown that the academic interest in this area has gradually increased from 1977 to 2020.

Author Contributions: Conceptualization, F.S., A.K. and S.U.R.; methodology, S.U.R. and M.A.; software, S.U.R. and M.A.; validation, F.S., A.K. and S.U.R.; formal analysis, SUR and M.A.; data curation, F.S., A.K., S.U.R. and M.A.; writing—original draft preparation/review and editing, F.S., A.K., S.U.R. and M.A.; visualization, S.U.R. and M.A.; supervision, F.S. and A.K.; project administration, F.S., A.K. and S.U.R. All authors have read and agreed to the published version of the manuscript.

Funding: The research received no external funding.

Institutional Review Board Statement: Not applicable.

Informed Consent Statement: Not applicable.

Acknowledgments: The authors would like to acknowledge the support of Prince Sultan University for paying the Article Processing Charges (APC) of this publication.

Conflicts of Interest: The authors declare no conflict of interest.

\section{References}

1. Polonsky, M.J. A stakeholder theory approach to designing environmental marketing strategy. J. Bus. Ind. Mark. 1995, 10, 29-46. [CrossRef]

2. Polonsky, M.J. An introduction to green marketing. Electron. Green J. 1994, 1, 1-11. [CrossRef] 
3. Martin, D.M.; Schouten, J. Sustainable Marketing; Pearson: Noida, UP, India, 2015.

4. Milanović, T.; Popović, V.M.; Vučković, S.; Rakaščan, N.; Popović, S.; Petković, Z. Analysis of soybean production and biogas yield to improve eco-marketing and circular economy. Eco. Agric. 2020, 67, 141-156. [CrossRef]

5. Menon, A.; Menon, A. Enviropreneurial marketing strategy: The emergence of corporate environmentalism as market strategy. J. Mark. 1997, 61, 51-67. [CrossRef]

6. Song-Turner, H.; Polonsky, M. Enviropreneurial marketing in greening corporate activities: Evidence from four Chinese green firms. Eur. Bus. Rev. 2016, 28, 506-531. [CrossRef]

7. Baker, W.E.; Sinkula, J.M. Environmental Marketing Strategy and Firm Performance: Effects on New Product Performance and Market Share. J. Acad. Mark. Sci. 2005, 33, 461-475. [CrossRef]

8. Leonidou, C.N.; Leonidou, L.C. Research into environmental marketing/management: A bibliographic analysis. Eur. J. Mark. 2011, 45, 68-103. [CrossRef]

9. Peattie, K.; Charter, M. Green Marketing. In The Marketing Book, 5th ed.; Baker, M.J., Ed.; Butterworth-Heinemann: New York, NY, USA, 2003; pp. 726-755.

10. Dennis, C.; Harris, L.; Peattie, K.; Crane, A. Green marketing: Legend, myth, farce or prophesy? Qual. Market Res. Int. J. 2005, 8, 357-370.

11. Khattak, A. Green innovation in south Asia's clothing industry: Issues and challenges. In Sustainable Economy and Emerging Markets; Paladini, S., George, S., Eds.; Routledge: New York, NY, USA, 2019; pp. 172-183.

12. Saleem, F.; Zhang-Zhang, Y.; Malik, M.I.; Allui, A. Revisiting Stakeholder Theory and Environmentalism: Evidence from an Emerging Economy. Sustainability 2020, 12, 8751. [CrossRef]

13. Andreoni, V. Environmental taxes: Drivers behind the revenue collected. J. Clean. Prod. 2019, 221, 17-26. [CrossRef]

14. Durisin, B.; Calabretta, G.; Parmeggiani, V. The Intellectual Structure of Product Innovation Research: A Bibliometric Study of the Journal of Product Innovation Management, 1984-2004. J. Prod. Innov. Manag. 2010, 27, 437-451. [CrossRef]

15. Garfield, E. Citation Indexing: Its Theory and Application in Science, Technology, and Humanities; Wiley: New York, NY, USA, 1979; Volume 8.

16. Nicolas, C.; Valenzuela-Fernández, L.; Merigó, J.M. Research Trends of Marketing: A Bibliometric Study 1990-2017. J. Promot. Manag. 2020, 26, 674-703. [CrossRef]

17. Lacka, E.; Chan, H.K.; Wang, X. Technological advancements and B2B international trade: A bibliometric analysis and review of industrial marketing research. Ind. Mark. Manag. 2020, 88, 1-11. [CrossRef]

18. Martínez-López, F.J.; Merigó, J.M.; Gázquez-Abad, J.C.; Ruiz-Real, J.L. Industrial marketing management: Bibliometric overview since its foundation. Ind. Mark. Manag. 2020, 84, 19-38. [CrossRef]

19. Perannagari, K.T.; Chakrabarti, S. Analysis of the literature on political marketing using a bibliometric approach. J. Public Aff. 2020, 20, 1-13. [CrossRef]

20. Ribeiro, M.I.B.; Fernandes, A.J.G.; Lopes, I.M. Digital marketing: A bibliometric analysis based on the Scopus database scientific publications. In Digital Marketing Strategies and Models for Competitive Business; IGI Global: Pennsylvania, PA, USA, 2020; pp. 52-73.

21. Chabowski, B.R.; Mena, J.A.; Gonzalez-Padron, T.L. The structure of sustainability research in marketing, 1958-2008: A basis for future research opportunities. J. Acad. Mark. 2011, 39, 55-70. [CrossRef]

22. Díez-Martín, F.; Blanco-González, A.; Prado-Román, C. Research Challenges in Digital Marketing: Sustainability. Sustainablity 2019, 11, 2839. [CrossRef]

23. Dangelico, R.M.; Vocalelli, D. "Green Marketing": An analysis of definitions, strategy steps, and tools through a systematic review of the literature. J. Clean. Prod. 2017, 165, 1263-1279. [CrossRef]

24. Kumar, P.; Ghodeswar, B. Green Marketing Mix: A Review of Literature and Direction for Future Research. I. J. Asian Busi. Inf. Manag. 2015, 6, 42-59. [CrossRef]

25. Andreoli, T.P.; Crespo, A.; Minciotti, S. What has been (short) written about greenwashing: A bibliometric research and a critical analysis of the articles found regarding this theme. Rev. Gestão Soc. Ambient. RGSA 2017, 11, 54. [CrossRef]

26. Harper, G.; Peattie, K. Tracking the influence of the first special journal issue on 'Green Marketing': A citation network analysis. Soc. Bus. 2011, 1, 239-261. [CrossRef]

27. Clarivate Web of Science: Confident Research Begins Here. Available online: https://clarivate.com/webofsciencegroup/ solutions /web-of-science/ (accessed on 17 June 2020).

28. Web of Science Core Collection Field Tags. Available online: https://images.webofknowledge.com/images/help/WOS/hs_ wos_fieldtags.html (accessed on 6 July 2020).

29. Zhou, W.; Kou, A.; Chen, J.; Ding, B. A retrospective analysis with bibliometric of energy security in 2000-2017. Energy Rep. 2018, 4, 724-732. [CrossRef]

30. Zhong, S.; Geng, Y.; Liu, W.; Gao, C.; Chen, W. A bibliometric review on natural resource accounting during 1995-2014. J. Clean. Prod. 2016, 139, 122-132. [CrossRef]

31. Feng, Y.; Zhu, Q.; Lai, K.-H. Corporate social responsibility for supply chain management: A literature review and bibliometric analysis. J. Clean. Prod. 2017, 158, 296-307. [CrossRef]

32. Roe, B.; Teisl, M.F.; Levy, A.; Russell, M. US consumers' willingness to pay for green electricity. Energy Policy 2001, 29, 917-925. [CrossRef] 
33. Zhu, Q.; Sarkis, J.; Geng, Y. Green supply chain management in China: Pressures, practices and performance. Int. J. Oper. Prod. Manag. 2005, 25, 449-468. [CrossRef]

34. Hartmann, P.; Apaolaza-Ibáñez, V. Consumer attitude and purchase intention toward green energy brands: The roles of psychological benefits and environmental concern. J. Bus. Res. 2012, 65, 1254-1263. [CrossRef]

35. Kumar, P. State of green marketing research over 25 years (1990-2014). Mark. Intell. Plan. 2016, 34, 137-158. [CrossRef]

36. Tilt, C.A. Making social and environmental accounting research relevant in developing countries: A matter of context? Soc. Environ. Account. J. 2018, 38, 145-150. [CrossRef]

37. Khattak, A. A Comparative Analysis of South Asian Apparel Firms in Global Value Chains: Governance, Institutions and Upgrading. Ph.D. Thesis, University of Auckland, Auckland, New Zealand, 2013.

38. Waxin, M.F.; Knuteson, S.L.; Bartholomew, A. Drivers and challenges for implementing ISO 14001 environmental management systems in an emerging Gulf Arab country. Environ. Manag. 2017, 63, 495-506. [CrossRef]

39. Saleem, F.; Gopinath, C.; Khattak, A.; Qureshi, S.S.; Allui, A.; Adeel, A. Corporate Environmentalism: An Emerging Economy Perspective. Sustainability 2020, 12, 6225. [CrossRef]

40. Bebbington, J.; Unerman, J. Achieving the United Nations sustainable development goals. Account. Audit Account. J. 2019, 31, 107-125. [CrossRef]

41. Grainger-Brown, J.; Malekpour, S. Implementing the Sustainable Development Goals: A Review of Strategic Tools and Frameworks Available to Organisations. Sustainability 2019, 11, 1381. [CrossRef]

42. Muscio, A.; Quaglione, D.; Vallanti, G. Does government funding complement or substitute private research funding to universities? Res. Policy. 2013, 42, 63-75. [CrossRef]

43. Luchs, M.G.; Naylor, R.W.; Irwin, J.R.; Raghunathan, R. The sustainability liability: Potential negative effects of ethicality on product preference. J. Mark. 2010, 74, 18-31. [CrossRef]

44. Hayati, Z.; Didegah, F. International scientific collaboration among Iranian researchers during 1998-2007. Libr. HiTech. 2010, 28, 433-446. [CrossRef]

45. Gazni, A.; Sugimoto, C.R.; Didegah, F. Mapping world scientific collaboration: Authors, institutions, and countries. J. Am. Soc. Inf. Sci. Tec. 2012, 63, 323-335. [CrossRef]

46. Knowledge, Networks and Nations: Global Scientific Collaboration in the 21st Century. Available online: http:/ / sro.sussex.ac. $\mathrm{uk} / \mathrm{id} /$ eprint/45410 (accessed on 11 July 2020).

47. Henion, K.; Kinnear, T. Ecological Marketing; American Marketing Association: Chicago, IL, USA, 1976.

48. Peattie, K. Environmental Marketing Management: Meeting the Green Challenge; Financial Times Management: Upper Saddle River, NJ, USA, 1995.

49. Ye, N.; Tung-Boon, K.; Lisong, H.; Yongxin, L.; Hang, Y. A Bibliometric Analysis of Corporate Social Responsibility in Sustainable Development. J. Clean. Prod. 2020, 272, 122679. [CrossRef] 